\title{
DEREGULATION OF CANCER-ASSOCIATED GENES IN ODONTOGENIC CYSTS
}

\section{ABSTRACT}

Objectives: The aim of the present study was to demonstrate the key role of differential expression levels of RB1, TP53, XIAP, BCL2 AIFM3, BAX, CASP3 and CASP9 genes in odontogenic cysts.

Materials and Methods: A total number of 15 patients who diagnosed with odontogenic cyst were enrolled for the present study. For the quantitative gene expression analysis, cyst and adjacent gingival healthy tissues of patients were collected during surgical assessments. Quantitative analysis of gene expression levels RB1, TP53, XIAP, BCL2 AIFM3, BAX, CASP3 and CASP9 were achieved real-time PCR method. For the optimization of gene expression levels GAPDH reference gene was used.

Results: Expression of both RB1 and TP53 genes were markedly diminished in odontogenic cysts tissues as compared to healthy tissues $(p<0.05)$. Likewise, levels of CASP3 and CASP9 genes were found to be significantly reduced in odontogenic cysts tissues compared to healthy tissues $(p<0.05)$. In contrast, expression levels of XIAP was significantly elevated $(\mathrm{p}<0.05)$. Although BCL2, AIFM3, and BAX genes were also differentially expressed in odontogenic cysts tissues, these variations were statistically insignificant ( $p>0.05)$.

Conclusions: The findings of the present study indicates that RB1, TP53, XIAP, CASP3 and CASP9 genes might have chief roles in formation odontogenic cysts and responsible for the increased cell proliferation in these tissues.

Keywords: Gene expression, odontogenic cysts, tumor suppressor genes.
*Bilal Ege ${ }^{1}$

iD Önder Yumrutaş²

(iD) İbrahim Bozgeyik ${ }^{3}$

ORCID IDs of the authors: B.E. 0000-0002-1279-0893 O.Y. 0000-0001-9657-8306 I.B. 0000-0003-1483-2580
Received : : 24.03.2019 Accepted : $: 15.04 .2019$ 


\section{INTRODUCTION}

Cysts are pathological cavities which are surrounded by epithelial connective tissue capsule filled with fluid or semi-fluid material. Cysts are most commonly seen in jaws compared to other parts of the body, as epithelial debris in these regions is more abundant than other parts of the body. ${ }^{1}$ Radicular cysts are the most frequently encountered odontogenic cysts and originate from a previously formed apical granuloma in the apical region of a necrotic tooth. These cysts are formed by the proliferation of malessez epithelial residues. $^{2,3}$ Dentigerous cysts are cysts that surround the crown of the unerupted or partially erupted teeth. After the formation of the tooth crown, fluid accumulation between tooth enamel epithelium and the tooth crown and additionally proliferation of epithelial islets in the dental follicle wall leads to cyst formation. Approximately $24 \%$ of odontogenic cysts are dentigerous cysts and second most common odontogenic cysts seen after radicular cysts., Odontogenic keratocysts, which originates from odontogenic epithelial wastes and the basal layer of the oral epithelium, are considered to be the most aggressive odontogenic cyst and more likely to transform into a malignancy due to local aggressive course, high residual rate and invasion to surrounding tissues. ${ }^{6-9}$

Besides, molecular pathogenesis of carcinogenesis involves the accumulation of mutations in oncogenes and tumor suppressor genes and these genetic aberrations are the very early sign of a malignant transformation. ${ }^{10}$ In consequence, oncogenes and tumor suppressor genes are the crucial components that drive the formation of cancers. ${ }^{10,11}$ Mutations can lead to hyper- or hypo-activity of an oncogene and tumor suppressor gene, respectively. So far, several genes with oncogenic and tumor suppressor functions have been identified to be associated with the development and progression of human cancers. ${ }^{10,11}$ Chiefly, deregulation of these genes have been shown to be well-correlated with poor prognosis and clinicopathological characteristics of patients and experimentally associated with the increased proliferation, invasion, migration and metastasis of cancer cells in vitro. ${ }^{10,11}$

Moreover, accumulating body of evidence suggest that several cancer biomarkers were revealed to be deregulated in odontogenic cysts. Particularly, immunohistochemical analysis of Cyclin D1, BCL2, PCNA, P53 ${ }^{12,13}$, COX-2 $2^{14}$, Ki67, P63 $3^{15,16}$ HIF- $1 \alpha$ and Caspase $3^{17}$ proteins revealed that these proteins markedly involved in pathobiology of odontogenic cysts and associated with the clinicopathological characteristics of patients. Nevertheless, these findings were limited to immunohistochemistry method and a few numbers of markers were investigated. Apart from these studies, we used quantitative PCR approach which is a cost-effective and less time-consuming method enabling rapid quantitative analysis gene expression levels.

Consequently, in this particular study, our aim was to elucidate the roles of differential expression levels of RB1 (Retinoblastoma 1), TP53 (Tumor Protein P53), XIAP (X-linked inhibitor of apoptosis), AIFM3 (Apoptosis inducing factor, mitochondria associated 3), BAX (BCL2 associated X, apoptosis regulator), CASP3 (Caspase 3) and CASP9 (Caspase 3) genes, which have been known to be associated with the formation and progression of several types of cancers, in odontogenic cysts of radicular, dentigerous and odontogenic keratocyst epithelium and their association with local aggressive behavior and osteolytic properties of these cysts. In particular, expression levels of RB1, TP53, XIAP, BCL2 AIFM3, BAX, CASP3 and CASP9 genes were measured by Real-Time Polymerase Chain Reaction (PCR) method.

\section{MATERIALS AND METHODS}

\section{Study population and sample collection}

Total numbers of 15 patients who admitted to clinic of Department of Oral and Maxillofacial Surgery with the various symptoms (pain, swelling, etc.) and diagnosed with odontogenic cyst were enrolled in the study. Clinical and demographical features of age, gender, anatomic localization of tooth and pathological diagnosis of patients were shown in Table 1. Among these patients, 4 (26.6\%) were odontogenic keratocyst, 
$3(20 \%)$ were dentigerous cyst and 8 of them were $8(53.4 \%)$ radicular cyst (Table 1). Patients included in the study were subjected to routine examination and panoramic radiographs were obtained. Exclusion criteria for the study was presence of systemic disease, infection in the operation area, presence of systemic viral, fungal, or bacterial infection, sensitivity to drugs and anesthetics, cigarette or alcohol addiction, pregnancy or lactation.

Table 1. Demographic and clinicopathological characteristics of patients

\begin{tabular}{lll}
\hline Parameters & & $\mathbf{n = 1 5 ( \% )}$ \\
\hline Age & & $34.8 \pm 23.99$ \\
Gender & Male & $6(40.0)$ \\
& Female & $9(60.0)$ \\
& Mandibula right anterior & $1(6.67)$ \\
Localization of Tooth & Mandibula left posterior & $2(13.3)$ \\
& Maxilla right anterior & $3(20)$ \\
& Maxilla left anterior & $6(40)$ \\
Pathological diagnosis & Mandibula right posterior & $3(20)$ \\
& Odontogenic keratocyst & $4(26.6)$ \\
\hline
\end{tabular}

For the study, tissues and adjacent healthy tissues of patients were collected during surgical operation. Collected tissue samples of patients were stored at $-80{ }^{\circ} \mathrm{C}$ for expression analysis. Also, every tissues sample were subjected to pathological examination prior to inclusion in the study. A written informed consent was obtained from all individuals participated in the study.

\section{Isolation of total RNA from tissue samples}

GeneJET RNA Purification Kit (Thermo Fisher Scientific Inc., Wilmington, USA) was used for the isolation of total RNA from tissue samples. Briefly, $30 \mathrm{mg}$ of tissue samples were homogenized in $300 \mu$ lysis buffer containing $\beta$ mercaptoethanol (Sigma-Aldrich, MO, USA) by using TissueLyser LT (QIAGEN Sample \& Assay Technologies, Germany) and instructions of the manufacturer were followed to obtain RNA. To ensure any RNase contamination RNase AWAY Decontamination Reagent (Thermo Fisher Scientific Inc., Wilmington, USA) was used. Quantities and concentrations of isolated RNA samples were measured by using NanoDrop 2000 UV-Vis Spectrophotometer (Thermo Fisher Scientific Inc., Wilmington, USA) and stored $80^{\circ} \mathrm{C}$ in equal aliquots.

\section{Synthesis of complementary DNA from RNA samples}

Complementary DNA was synthesized by using RevertAid First Strand cDNA Synthesis Kit (Thermo Fisher Scientific Inc., Wilmington, USA). Briefly, $4 \mu 1$ of $5 \mathrm{X}$ Reaction Buffer, $1 \mu 1$ of RiboLock RNase Inhibitor, $1 \mu 1$ of $10 \mathrm{mM}$ dNTP Mix, $1 \mu 1$ of RevertAid Reverse Transcriptase, and $1 \mu \mathrm{l}$ of Random Hexamer and variable amounts of ddH2O and RNA samples were mixed and distributed to $0.2 \mathrm{ml}$ PCR tubes. The prepared PCR mix was subjected to following thermal cycling protocol; $5 \mathrm{~min}$ at $25^{\circ} \mathrm{C}, 60 \mathrm{~min}$ at $42^{\circ} \mathrm{C}$ and for the termination of reaction $5 \mathrm{~min}$ at $70^{\circ} \mathrm{C}$. Subsequently, samples were placed on ice block and transferred to $-80^{\circ} \mathrm{C}$ until further application.

\section{Primer Design and Analysis of gene expression by Real-Time PCR}

Appropriate expression primers were designed using the "Primer-blast" interface of National Center for Biotechnology Information (NCBI) database (https://www.ncbi.nlm.nih.gov/tools/primer-blast/) to analyze the expression of the genes of interest. The primers and their properties used in the analysis of mRNA expressions. For the analysis of the expressions of RB1, TP53, XIAP, BCL2 AIFM3, BAX, CASP3 and CASP9 genes, we used RealQ Plus 2x Master Mix Green without ROX $^{\mathrm{TM}}$ (Ampliqon PCR Enzymes \& Reagents, Odense M, Denmark). Briefly, for each reaction 
$12.5 \mu 1$ of RealQ Plus 2x Master Mix, $0.5 \mu 1$ of Forward primer, $0.5 \mu \mathrm{l}$ of Reverse primer, $2 \mu \mathrm{l}$ of cDNA and $9.5 \mu \mathrm{l}$ of PCR-grade $\mathrm{H} 2 \mathrm{O}$ was used. Real-time PCR reactions were carried out in Rotor-Gene Q instrument (QIAGEN Sample \& Assay Technologies, Germany). For the reactions, tree-step cycling PCR program including $15 \mathrm{~min}$ at $95^{\circ} \mathrm{C}$ initial denaturation and 30 seconds at $95^{\circ} \mathrm{C}, 30$ seconds at $60^{\circ} \mathrm{C}$ and 30 seconds at $72^{\circ} \mathrm{C}$ for 40 cycle was performed. Also, a melting curve analysis between 60 and $95^{\circ} \mathrm{C}$ immediately was performed after PCR to ensure PCR efficiency. All reactions were studied in triplicate.

\section{Data Analysis}

Gene expression levels were calculated by $2^{-\Delta \mathrm{Ct}}$ $(\Delta \mathrm{Ct}=$ Target gene - Reference gene $)$ method. GAPDH reference gene was used to normalize resulting expression data. GraphPad Prism (Version 6 for Windows) statistical analysis software was used to analyze statistical changes. For the statistical comparisons, Wilcoxon matched-pairs signed rank test was applied during analysis. All statistics were two-tailed and $\mathrm{p}<0.05$ were accepted as statistically significant.

\section{Ethics statement}

This present study was reviewed in accordance to the Declaration of Helsinki on medical protocol and ethics. The regional Ethical Review Board of Adiyaman University Ethics Committee approved the study (Approval Number: 2018/1-7).

\section{RESULTS}

As a result of the gene expression analysis, we identified significant gene expression variations in odontogenic cysts. In particular, relative gene expression levels of two well-known tumor suppressor genes, RB1 $(\mathrm{p}=0,0479)$ and TP53 $(p=0.0054)$ were found to be significantly decreased in tissues of odontogenic cysts as compared to adjacent gingival healthy tissue of patients (Fig 1).
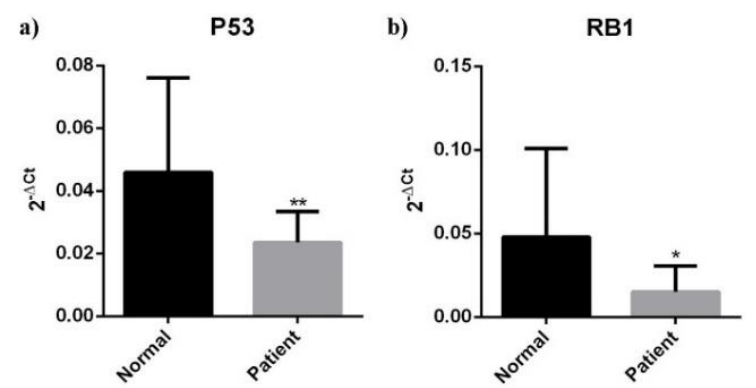

Fig 1. Quantitative expression levels of P53 and RB1 genes in tissues of odontogenic cysts as compared to adjacent gingival healthy tissue of patients.

In addition, gene expression levels of CASP3 $(\mathrm{p}=0.0085)$ and CASP9 $(\mathrm{p}=0.0479)$, which are involved in the intrinsic pathway of apoptosis, were found to be significantly reduced in tissues of odontogenic cysts as compared to adjacent gingival healthy tissue of patients (Fig 2). Also, gene expression level of XIAP (0.0353), which is an apoptosis inhibitor gene, was found to be significantly advanced in tissues of odontogenic cysts as compared to adjacent gingival healthy tissue of patients. Moreover, gene expression level of AIFM3 ( $p>0.05$ ), an apoptosis inducing gene, was also found to be diminished but this variation was statistically not significant (Fig 2).
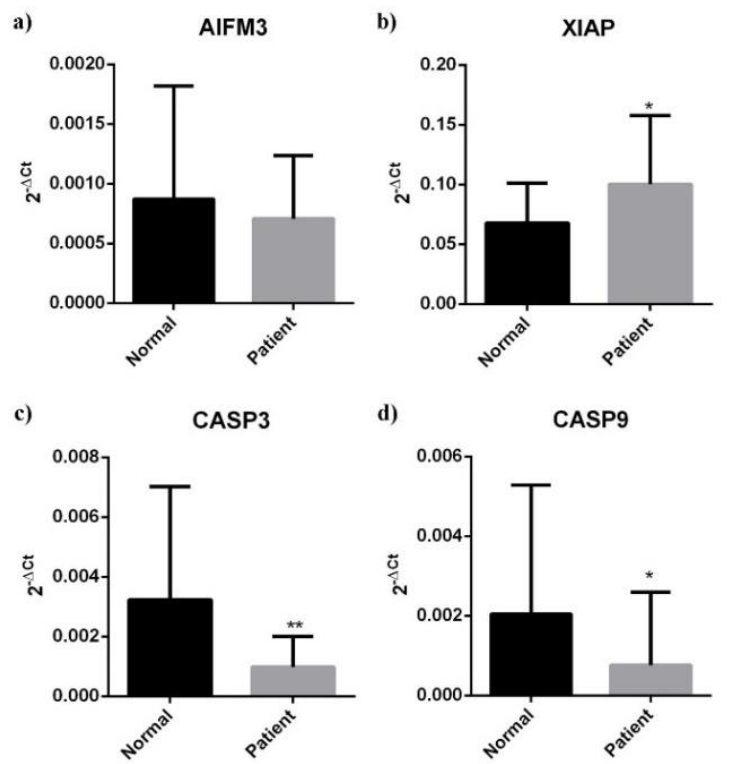

Fig 2. Quantitative expression levels of AIFM3, XIAP, CASP3 and CASP9 genes in tissues of odontogenic cysts as compared to adjacent gingival healthy tissue of patients.

Furthermore, gene expression level of proapoptotic BAX gene was found to be increased in tissues of odontogenic cysts as compared to adjacent gingival healthy tissue of patients (Fig 3). Also, BCL2 gene expression levels were found to 
be reduced in issues of odontogenic cysts as compared to adjacent gingival healthy tissue of patients (Fig 3). However, changes in the expression levels of BAX and BCL2 were statistically insignificant $(\mathrm{p}>0.05)$.
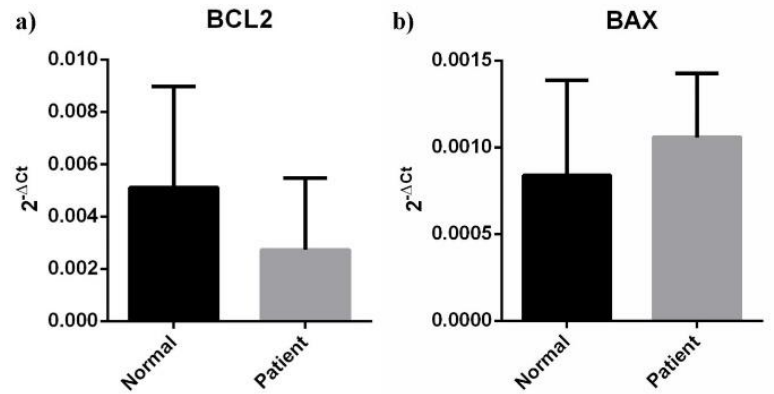

Fig 3. Quantitative expression levels of BCL2 and BAX genes in tissues of odontogenic cysts as compared to adjacent gingival healthy tissue of patients.

\section{DISCUSSION}

Increasing mass of evidence indicate that several proteins participated in the formation and progression of tumors are also deregulated in odontogenic cysts. Previous work by Kaczmarzyk et al. ${ }^{14}$ analysed immunoexpression of PCNA, P53, COX-2, and BCL-2 and reported that these proteins are involved in the physiopathology of odontogenic keratocyst and expression of these proteins were associated with the radiographic evidence of cortical perforation and age of patients. Fatemeh et al. ${ }^{12}$ also reported significant differential expression of p53 protein in odontogenic cysts. In particular, they established that p53 is highly positive in inflamed odontogenic keratocyst in contrast to noninflamed odontogenic keratocyst and p53 expression highly decreased in dental follicles.

Furthermore, in a separate study, differential up-regulation of HIF- $1 \alpha$ and CASPASE-3 by determined by immunohistochemistry. Particularly, expression of HIF-1 $\alpha$ was higher in radicular cyst, dentigerous cyst, and ameloblastoma as compared to dental follicle tissues. ${ }^{17}$ These findings strongly suggest the contribution of HIF- $1 \alpha$ and CASPASE3 in the formation of odontogenic cysts and tumors. Moreover, Gadbail et al. ${ }^{15}$ also demonstrated the role of Ki-67 and p53 in odontogenic keratocyst and ameloblastoma and found that both $\mathrm{Ki}-67$ and p53 expressions are elevated in ameloblastoma as compared to odontogenic keratocyst. Also, both Ki-
67 and p53 expressions were advanced in odontogenic keratocyst than dentigerous cyst, suggesting Ki-67 and p53 protein expression might be useful prognostic biomarker in odontogenic lesions. Sreedhar et al. ${ }^{18}$ also established the expression status of PCNA and BCL-2 proteins in odontogenic keratocyst and dentigerous cyst. Particularly, they showed that while PCNA was markedly increased, Bcl-2 was significantly markedly in odontogenic keratocyst and dentigerous cyst. ${ }^{18}$ In a different study comprising p53, Bcl-2 and Bax proteins, while expression of p53 and Bcl-2 was found to be positively correlated, expression of p53 and Bax protein was found to be negatively correlated. ${ }^{19}$

In line with these findings, in tissues of odontogenic cysts, we also identified significant genetic alterations in genes significantly involved in the formation and progression of human cancers. As we all know, loss of tumor suppressive activity is the initial step in formation of tumors and deregulation of these two has been muchly reported in several types of neoplastic growths and cancers. ${ }^{20}$ TP53 has been known as "the guardian of genome" because it is activated in harsh conditions, especially in case of DNA damage. ${ }^{20}$ Once the TP53 is activated, it temporally arrests cell cycle at the G1 phase to allow DNA repair if the DNA damage is reversible. Alternatively, if the damage is irreversible TP53 forces cells to die by apoptosis. ${ }^{21}$ In our study, expression levels of both RB1 and TP53 tumor suppressor genes were found to be significantly reduced in tissues of odontogenic cysts. Our results are also consistent with the previous immunohistochemistry studies. Thus, these findings suggest that these two genes might have important roles in the formation of these cysts and might be reliable biomarkers in characterization of these cysts.

Additionally, deregulation of apoptotic mechanisms is a chief contributor of the development of various types of disease ranging from cancer to neurological disorders and might have significant influence in developing therapeutic strategy. ${ }^{22}$ Particularly, growing evidence suggests that tumor cells are extremely 
resistant to apoptotic cell death which eliminates damaged cells. ${ }^{22}$ Resistant to apoptosis emerges as a result of differential overexpression of antiapoptotic genes such as Bcl-2 and IAP (inhibitors of apoptosis proteins) family of proteins or reduced expression of pro-apoptotic members such as Bid and Bax..$^{22,23}$ Similar to tumors, odontogenic cysts can also acquire resistance programmed cell death by deregulation of proapoptotic and anti-apoptotic protein members as we mentioned above. Accordingly, we also evaluated the gene expression levels of proapoptotic and anti-apoptotic members of the programmed cell death pathway as well as protein involved in the initiation (caspase-9) and execution (caspase-3) phases of apoptosis. As a result, we recognized that while gene expression levels of anti-apoptotic XIAP was significantly increased in odontogenic cysts, expression levels of apoptosis initiator caspase- 9 and executioner caspase- 3 was found to be significantly decreased in odontogenic cysts as compared to adjacent gingival healthy tissue of patients. Our findings are also consistent with previous findings about caspase-3 protein expression in immunohistochemistry. These findings supports the notion that apoptosis pathway is markedly deregulated in the formation and progression of odontogenic cysts.

Taken together, odontogenic cysts seems to be acquire molecular changes acquired by tumors by downregulation of tumor suppressor and proapoptotic proteins and up-regulation of antiapoptotic proteins. Here, we identified significant differential expression of genes involved in the formation and progression of tumors.

\section{CONCLUSIONS}

In conclusion, the findings of the present study indicates that RB1, TP53, XIAP, CASP3 and CASP9 might have significant impact in formation odontogenic cysts and responsible for the increased cell proliferation in these tissues. On the other hand, there are several limitations of our study. The most important one is the small sample size. In the upcoming studies, it is of great interest to determine the role of these genes in larger study populations. Also, comparing the gene expression results between types of odontogenic cysts is of great interest. Further in vitro studies might also be conducted to demonstrate the functional roles of these genes in the cysts development. Lastly, identifying microRNA and long non-coding RNA regulators of these genes is of great interest to illuminate exact mechanism of pathogenesis.

\section{ACKNOWLEDGMENTS}

\section{None}

\section{CONFLICT OF INTEREST STATEMENT}

All authors declare no conflict of interest.

\section{Odontojenik Kistlerde Kanser İlişkili Genlerin \\ Düzensiz Ekspresyonu}

$\ddot{O} Z$

Amaç: Bu çalışmanın amacı odontojenik kistlerde RB1, TP53, XIAP, BCL2 AIFM3, BAX, CASP3 ve CASP9 genlerinin ayırt edici ekspresyonlarının ortaya konulmasıdır. Gereç ve Yöntemler: Bu çalışmaya odontojenik kist tanisı konulan toplam 15 hasta dahil edilmişstir. Gen ekspresyonu analizi için cerrahi operasyon sırasında hastaların kist ve bitişik gingival sağlıkl dokuları toplanmıştır. RB1, TP53, XIAP, BCL2 AIFM3, BAX, CASP3 ve CASP9 genlerinin kantitatif ekspresyon seviyelerinin belirlenmesi amacıla realtime PCR yöntemi kullanılmıştır. Gen ekspresyon seviyelerinin optimize edilmesi amactyla GAPDH referans geni kullanıld. Bulgular: Hem RBI hem de TP53 genlerinin ekspresyonu, sağlıkl dokularla karşılaştırıldı̆̆ında odontojenik kist dokularında belirgin bir şekilde azalmıştır $(p<0,05)$. Ayrıca, odontojenik kist dokularında CASP3 ve CASP9 genlerinde săglıklı dokularla karşılaştırıldı̆̆ında istatistiksel olarak anlamlı düşüş saptanmıştır (p<0,05). Buna karşılık, XIAP ekspresyonunun anlamlı olarak arttığ saptanmıştır $(p<0,05)$. Her ne kadar BCL2, AIFM3 ve BAX genleri de odontojenik kist dokularında ayırıcı bir şekilde eksprese edilmiş olsa da, bu değişikliklerin istatistiksel olarak anlamsız olduğu saptanmıştır $(p>0,05)$. Sonuçlar: $B u$ çalışmanın sonuçlarl, RB1, TP53, XIAP, CASP3 ve CASP9 genlerinin, odontojenik kistlerin oluşumunda önemli rol oynayabileceğini ve bu dokulardaki artan hücre çoğalmasindan sorumlu olabileceğini göstermektedir. Anahtar kelimeler: Gen ekspresyonu, odontojenik kistler, tümör baskllayıcı genler. 


\section{REFERENCES}

1. Nuñez-Urrutia S, Figueiredo R, Gay-Escoda C. Retrospective clinicopathological study of 418 odontogenic cysts. Med Oral Patol Oral Cir Bucal 2010;15:767-773.

2.Scholl RJ, Kellett HM, Neumann DP, Lurie AG. Cysts and cystic lesions of the mandible: clinical and radiologic-histopathologic review. Radiographics 1999;19:1107-1124.

3.Xiong J, Gronthos S, Bartold PM. Role of the epithelial cell rests of Malassez in the development, maintenance and regeneration of periodontal ligament tissues. Periodontology 2000 2013;63:217-233.

4.Benn A, Altini M. Dentigerous cysts of inflammatory origin: a clinicopathologic study. Oral Surg Oral Med Oral Pathol Oral Radiol Endod 1996;81:203-209.

5.Zhang L, Yang R, Zhang L, Li W, MacDonaldJankowski D, Poh C. Dentigerous cyst: a retrospective clinicopathological analysis of 2082 dentigerous cysts in British Columbia, Canada. Int $\mathrm{J}$ Oral Maxillofac Surg 2010;39:878-882.

6.Boffano P, Ruga E, Gallesio C. Keratocystic odontogenic tumor (odontogenic keratocyst): preliminary retrospective review of epidemiologic, clinical, and radiologic features of 261 lesions from University of Turin. J Oral Maxillofac Surg 2010;68:2994-2999.

7.Johnson NR, Batstone MD, Savage NW. Management and recurrence of keratocystic odontogenic tumor: a systematic review. Oral Surg Oral Med Oral Pathol Oral Radiol 2013;116:271-276.

8.Shear M. The aggressive nature of the odontogenic keratocyst: is it a benign cystic neoplasm? Part 1 . Clinical and early experimental evidence of aggressive behaviour. Oral oncology 2002;38:219-226.

9.Titinchi F, Nortje CJ. Keratocystic odontogenic tumor: a recurrence analysis of clinical and radiographic parameters. Oral Surg Oral Med Oral Pathol Oral Radiol 2012;114:136-142.

10.Bozgeyik E, Bayraktar E, Chavez-Reyes A, Rodriguez-Aguayo C . OncoLncs: Long Non-Coding RNAs with Oncogenic Functions. Mol Biol 2016;5:162.

11.Hanahan D, Weinberg RA. Hallmarks of Cancer: The Next Generation. Cell 2011;144:646-674.
12.Fatemeh M, Sepideh A, Sara BS, Nazanin M. P53 Protein Expression in Dental Follicle, Dentigerous Cyst, Odontogenic Keratocyst, and Inflammatory Subtypes of Cysts: An Immunohistochemical Study. Oman Med J 2017;32:227-232.

13.Ibrahim N, Nazimi AJ, Ajura AJ, Nordin R, Latiff ZA, Ramli R. The Clinical Features and Expression of bcl-2, Cyclin D1, p53, and Proliferating Cell Nuclear Antigen in Syndromic and Nonsyndromic Keratocystic Odontogenic Tumor. J Craniofac Surg 2016;27:13611366.

14.Kaczmarzyk T, Kisielowski $\mathrm{K}$, Koszowski R, Rynkiewicz M, Gawełek E, Babiuch K, Bednarczyk A, Drozdzowska B. Investigation of clinicopathological parameters and expression of COX-2, bcl-2, PCNA, and p53 in primary and recurrent sporadic odontogenic keratocysts. Clin Oral Investig 2018;5:1-10.

15.Gadbail AR, Patil R, Chaudhary M. Co-expression of Ki-67 and p53 protein in ameloblastoma and keratocystic odontogenic tumor. Acta Odontol Scand 2012;70:529-535.

16.Gurgel CA, Ramos EA, Azevedo RA, Sarmento VA, da Silva Carvalho AM, dos Santos JN. Expression of $\mathrm{Ki}-67, \mathrm{p} 53$ and p63 proteins in keratocyst odontogenic tumours: an immunohistochemical study. J Mol Histol 2008;39:311-316.

17. da Costa NMM, de Siqueira AS, Ribeiro ALR, da Silva Kataoka MS, Jaeger RG, de Alves-Júnior SM, Smith AM, de Jesus Viana Pinheiro J. Role of HIF-1 alpha and CASPASE-3 in cystogenesis of odontogenic cysts and tumors. Clin Oral Investig 2018;22:141-149.

18.Sreedhar G, Raju MV, Metta KK, Manjunath S, Shetty S, Agarwal RK. Immunohistochemical analysis of factors related to apoptosis and cellular proliferation in relation to inflammation in dentigerous and odontogenic keratocyst. J Nat Sci Biol Med 2014;5:112-115.

19.Tenório J, Santana T, Queiroz S, Queiroz L. Apoptosis and cell cycle aberrations in epithelial odontogenic lesions: An evidence by the expression of p53, Bcl-2 and Bax. Med Oral Patol Oral Cir Bucal 2018;23:120-125.

20.Efeyan A, Serrano M. p53: Guardian of the genome and policeman of the oncogenes. Cell Cycle 2007;6:1006-1010. 
21.Nylander K, Nilsson P, Mehle C, Roos G. P53 Mutations, Protein Expression and Cell-Proliferation in Squamous-Cell Carcinomas of the Head and Neck. Br J Cancer 1995;71:826-830.

22.Elmore S. Apoptosis: A review of programmed cell death. Toxicol Pathol 2007;35:495-516
23. Miyashita $\mathrm{T}$, Krajewski $\mathrm{S}$, Krajewska $\mathrm{M}$, Wang HG, Lin HK, Liebermann DA, Hoffman B, Reed JC. Tumor-Suppressor P53 Is a Regulator of Bcl-2 and Bax Gene-Expression in-Vitro and in-Vivo. Oncogene 1994;9:1799-1805. 